\title{
VALID BUSINESS DECISION-MAKING OF TOP MANAGEMENT IN MEDIUM ENTERPRISES ON THE EXAMPLE OF BUSINESS IN THE REPUBLIC OF SERBIA
}

Ivan Arnautovic, High School of Entrepreneurship, 11000 Beograd, Republic of Serbia, ivanarnautovic@gmail.com

Sanda Nastic, JKP Vodovod i Kanalizacija Novi Sad, Masarikova 17, 21000 Novi Sad, Serbia, kontroling.konsultant@gmail.com

Goran Vitomir, Nova Banka A.D. Banja Luka, Republika Srpska, Bosnia \& Herzegovina, g.vitomir85@gmail.com

Tatjana Davidov, Infostan Tehnologije D.O.O. Beograd, 11000 Beograd, Republic of Serbia tanja.davidov1@gmail.com

Slobodan Popovic, JKP Gradsko Zelenilo Novi Sad, Mladena Leskovca 1, 21000 Novi Sad, Republic of Serbia, Corresponding Author, slobodan.popovic49@gmail.com

\begin{abstract}
Valid business decision-making by top management in medium enterprises in size should be viewed as a permanent process that is aimed at achieving valid business decisions whose end effect is maximizing profit.

The process of valid business decision-making is of particular importance for the business of small and medium enterprises that form the basis of economic activity of transition countries. In such companies, there are accounts for the most extent of the capital critic in regular operations, especially medium enterprises.

In the mentioned companies, the leading utility decision is committed by making a leading utility decision, which increases the total expectation related to the total operations of enterprises in the transition economy. One of the important segments related to support for valid business decisions is the existence of an adequate IT sector in the company.

This work and activities can be improved in total management in the company. The basis for valid business decision-making is a prior adoption of a valid organizational scheme in a company in which the general scheme of the organization in the company will be presented.
\end{abstract}

Keywords: valid business decision, IT sector, internal control. 


\section{INTRODUCTION}

Top management in medium-sized enterprises such as the Republic of Serbia should possess determination in the implementation of valid business decision-making procedures that will aim to achieve the best business effects of business in the under time [1-3].

The process of making management decisions should be based on the application of rational commission of business decisions [4] in all parts of the company to make the effects of total business as efficient, better, higher, income higher, lower costs and secondly. This comes to a fore when connecting heterogeneous sectors in companies that essentially should function as a whole that will increase business efficiency.

Functional improvement in business decision-making by top management cannot be imagined without the formation of previous internal control in the processes of the overall panelling of the medium enterprises of transition countries. In addition, the importance of adopting a valid business decision is largely influenced by the realization of the final result of the company's business.

The adoption of a valid business decision by the top management is one of the essential segments or activities of top management, which will be able to improve both the current and business in the near future. Business decision is very linked to the application of numerous international standards that primarily link to the implementation of the same in the regular business [5-12].

Business decision is associated with the establishment of internal control and internal audit in the processes of regular operating enterprises of transitional economies [13-17]. To improve the total business, the most management should adopt a general management plan and activities in a company maximizing profits in a long-term business period [18-19].

Business decision is affecting increasing the level of business security within regular operations primarily of the middle companies of transitional countries. The authors in this paper draw attention to the importance of real business decision-making and making a real business decision.

In addition, business decision-making is of great importance for achieving the end result of business activity measured by increasing total income, reducing costs, increasing total turnover and other.

This occurs in particular in the medium enterprises of transitional economies such as the economy of the Republic of Serbia. 
They are targeted in themselves raised activities adopted by business decision-making principles, which is essentially aimed at achieving better overall business results and adopt valid business decisions that will monitor the meaning of the set business decision policy.

\section{ESTABLISHMENT OF INTERNAL CONTROL IN MEDIUM ENTERPRISES ON} THE EXAMPLE OF FUNCTIONING IN REAL CONDITIONS IN THE REPUBLIC OF SERBIA

The system of valid business decisions will be made to make management decisions inevitably meaning internal control and other functions such as internal audit in regular business operations, as well as the introduction of financial management and control in regular business in companies.

The valid system of established internal controls and internal audits at all levels of management in medium enterprises of transition countries has complete validity because it inevitably leads to improving overall management in companies.

The authors gave a view in Figure 1 possible schemes of introducing and establishing control mechanisms, which is to be realistic possible to improve the business of the medium enterprise.

By applying these controls, it is possible in transition economies, the total business, which is just happening in a large number of companies in the Republic of Serbia, especially in medium enterprises.

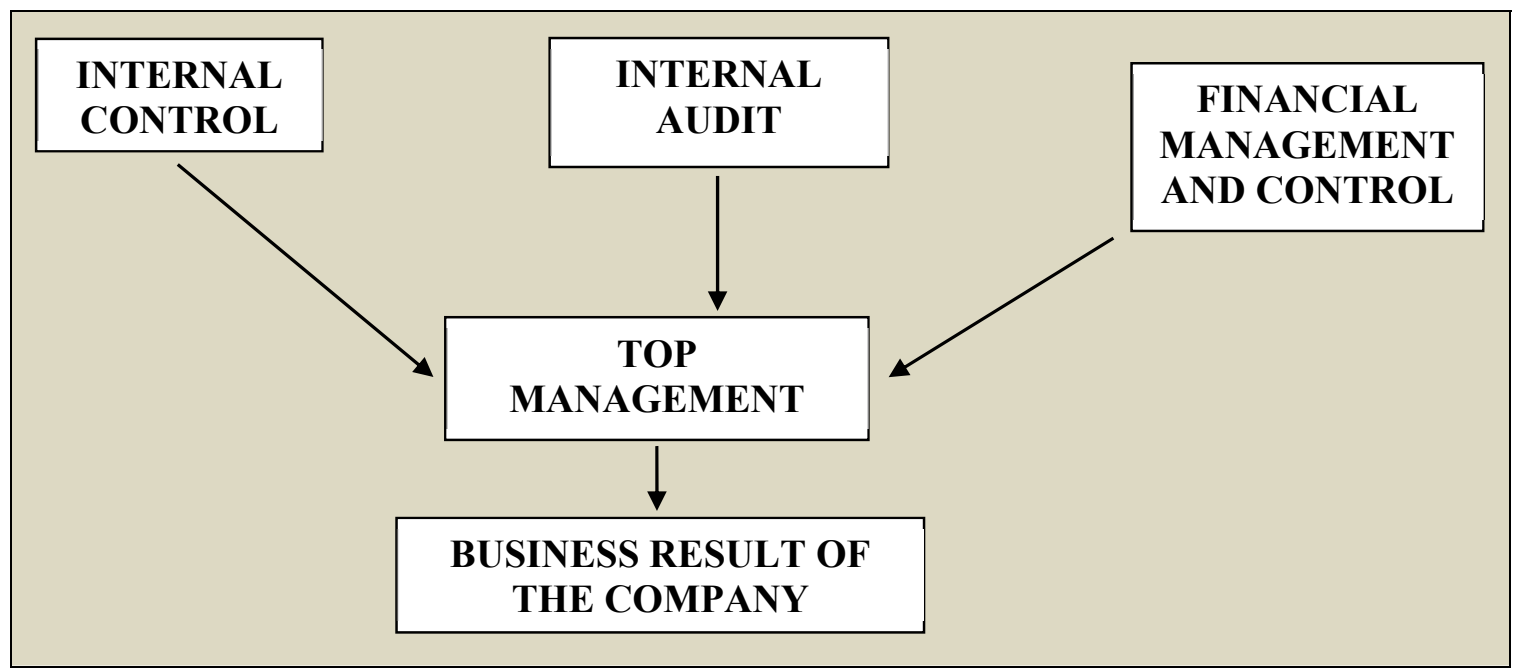

Fig. 1: Management model with regard to control mechanisms in companies. 
Controls and financial statements in enterprises should ensure that:

- show users whether the overall financial activities of that fiscal year were conducted in accordance with regulations,

- help users to better understand the nature, size and scope of the company's activities, as well as its financial condition,

- help customers understand and assess how the company finances its activities,

- help users to understand and evaluate the effects of the company's activities,

- help customers determine whether the company has achieved its goals,

- whether the costs have been correctly identified,

- provide users with information on the quantitative aspects of the company's income statement.

Users of financial statements include:

- employees in companies,

- external business partners such as creditors, suppliers and customers,

- economists, analysts and special interest groups,

- the media,

- financial statements include work that should be: understandable, relevant, reliable, material (significant), timely, consistent, comparable,

- balance sheet, including assets, liabilities and reserves,

- cash flow, which documents the sources and use of funds,

- notes to the financial statements that include a description of the accounting principles and methods used,

- other explanations as appropriate, which may include performance indicators.

\section{FREQUENCY OF REPORTING IN COMPANIES THAT INTRODUCED INTERNAL CONTROL IN ITS BUSINESS}

The frequency of internal control reporting in medium enterprises is performed with the aim of objective reporting, which is related to the costs of reporting and writing financial statements.

The method of reporting an internal auditor towards top management depends on the set and performed number of writing financial statements. Internal control should take into account 
the frequency of reports to be close to the financial and other reports to the optimum reporting according to the requested established controls performed by internal control for the purposes of the Mid-Enterprise Mean Management.

In the following authors Table 1 give the frequency of financial reporting as a basis for the acquisition of a valid internal control report that internal control delivers top management.

Table 1: Sample size viewed through different lengths of financial reporting of top management of Mid-

Enterprises

\begin{tabular}{|c|c|c|}
\hline \multirow[b]{2}{*}{ Frequency } & \multicolumn{2}{|c|}{$\begin{array}{c}\text { Sample } \\
\text { size }\end{array}$} \\
\hline & $\begin{array}{l}\text { Systems that are of key } \\
\text { (material) importance for } \\
\text { financial statements }\end{array}$ & $\begin{array}{c}\text { Systems that are subject to } \\
\text { cyclical checks }\end{array}$ \\
\hline Daily reporting & 30 & 18 \\
\hline Sunday & 5 & 5 \\
\hline Monthly & 2 & 4 \\
\hline
\end{tabular}

\section{APPLICATION OF SOFTWARE SOLUTIONS IN MEDIUM ENTERPRISES IN THE REPUBLIC OF SERBIA}

Development goal of introducing and developing software engineering in medium enterprises of transition countries, and in the Republic of Serbia aims to find new, predictable processes or methodologies, which would raise the level of overall management in companies.

Based on this, it can be concluded that the software project management process is a very responsible task for the needs of the medium enterprise software companies that develop software and in the given time and in relation to the budget.

It is most often used in the practice of software development and software development socalled. "Model of the waterfall". Namely, it is one of the traditional model in developing software solutions, with a sequential approach.

The mentioned model has its own and positive and negative impacts on the end product or to the supplied software contractor or medium enterprise. 
Software houses should evaluate the so-called. "Good" development practices of software solutions, according to:

- Iterative development of software,

- Managing user requirements and development team,

- Using component architecture,

- language for visual modelling,

- Continuous evaluation of the quality of development solutions and finished products,

- change management.

The authors are in the Figure 2 given a possible view of the development of software solutions in medium enterprises in the Republic of Serbia.

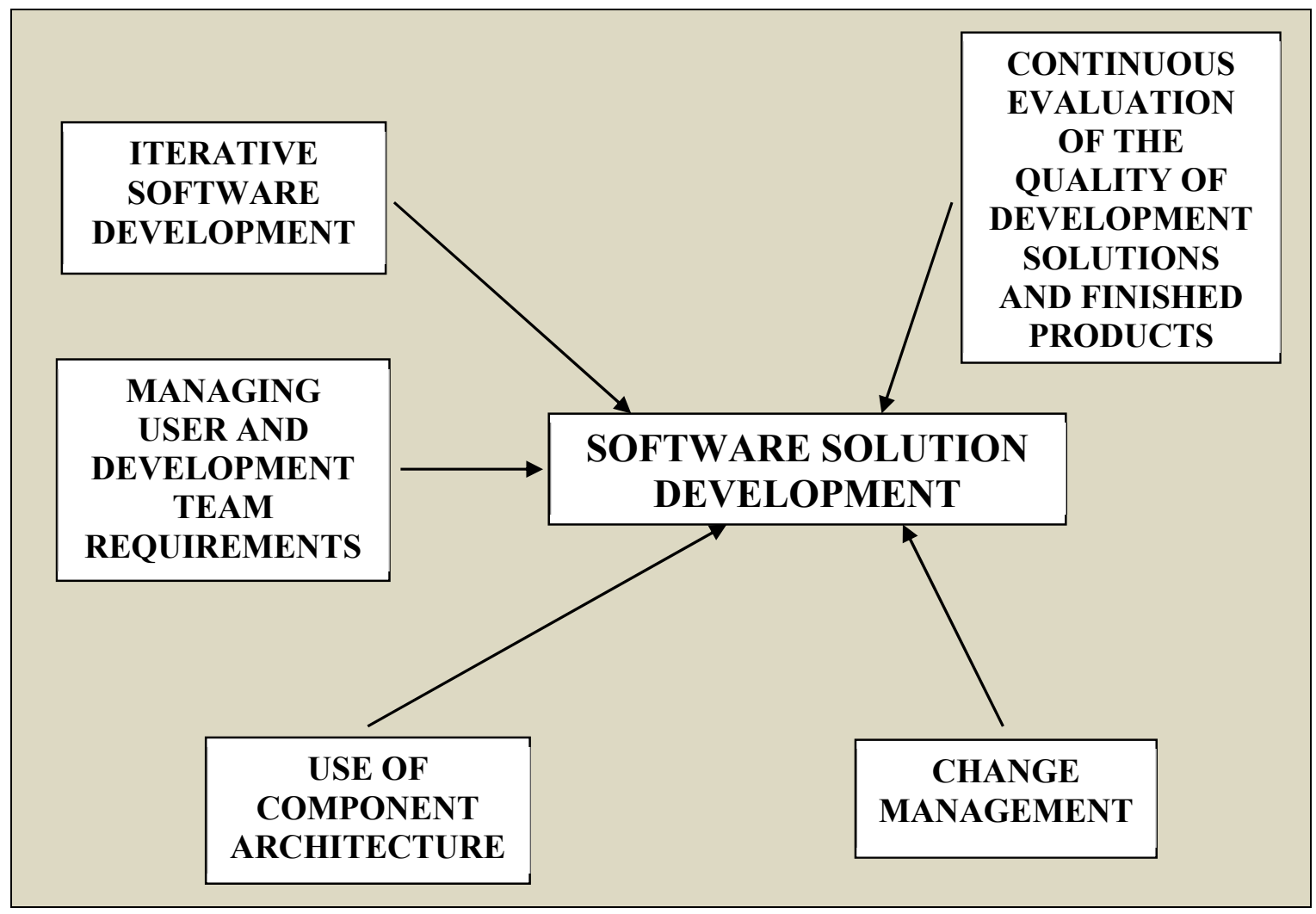

Fig. 2: Development of software solutions in the system of "good practice" in medium enterprises. 


\section{CONCLUSIONS}

Medium enterprises of transition countries such as the Republic of Serbia and which he stipulates the top management, can improve its total operations only if it introduces internal control mechanisms into its regular business.

The essential top management introduces internal control in all parts of the company. In this paper, the authors emphasized the importance of introducing internal control and development of the IT sector through the application of new software solutions by the top management of the Mid-Enterprise.

The results obtained were presented in the form of display in Table 1, which indicates the importance of the frequency of internal control to top management. In addition, they are presented in the form of figure No. 1, which given a general possible model of establishing control in medium enterprises in the Republic of Serbia. In the image figure No. 2 authors gave a possible development of software that has real use in medium enterprises in the Republic of Serbia.

Control can be implemented, primarily with respect for formed internal control and the goal is to improve the total business through the control of all business operations. Finally, it is important to point out that there is no such system of internal control that would provide perfect overall business results each time.

The authors point out that each established internal control or some other form of control that is implemented results in creating certain costs to be monitored and generally acceptable level for the normal functioning of the middle company.

\section{REFERENCES}

[1] Popović, S., Novaković, S., Đuranović, D., Mijić, R., Grublješić, Ž, Aničić, J., Majstorović, A. (2017). Application of international accounting standard-16 in a public company with predominantly agricultural activities, Economic Research-Ekonomska Istraživanja, 30(1): 1850-1864.

[2] Cantino, V. (2009). Korporativno uptravljanje, merenje performansi i normativna usaglašenost sistema internih kontrola, Beograd, Data Status.

[3] Mijić, R., Popović, S. (2016). Finansijsko Računovodstvo, Banja Luka: City print. 
[4] Majstorović, A., Popović, S., Volf, D. (2015). Teorija i politika bilansa, drugo izmenjeno i dopunjeno izdanje, Novi Sad: Feljton.

[5] Popović, S. (2014). Socio-ekonomski faktori ograničenja razvoja agrara, Monografija, Fimek, Novi Sad, Srbija.

[6] Popović, S., Ugrinović, M., Tomašević, S. (2015). Upravljanje menadžmenta poljoprivrednog preduzeća preko praćenja ukupnih troškova održavanja traktora, Poljoprivredna tehnika, 2: 101-106.

[7] Popović, S., Ugrinović, M., Tomašević, S. (2015). Management of Agricultural Enterprises by Means of Fair Financial Reporting in Accordance with International Standards of the Finance and Accounting Reporting, CDQM, Number 3: 24-30.

[8] Popović, S., Mijić, R., Grublješić, Ž. (2014). Interna kontrola i interna revizija u funkciji menadžmenta. Škola Biznisa, 1, 95-107.

[9] Popović, S., Tošković, J., Majstorović, A., Brkanlić, S., Katić, A. (2015). The importance of continuous audit of financial statements of the company of countries joining the EU, Annals of the „Constantin Brâncuşi” University of Târgu Jiu, Economy Series, Special Issue, 241-246.

[10] Bojović, R., Popović, V., Ikanović, J., Živanović, Lj., Rakaščan, N., Popović, S., Ugrenović, V \& Simić, D. (2019). Morphological characterization of sweet sorghum genotypes acrossen vironments, The J. Anim. Plant Sci. 29(3).

[11] Popović, S. (2015). Implementacija heterogenih rizika u radu interne revizije, Revizor 69.

[12] Vitomir, J., Tomaš-Miskin, S., Ivić, M., Popović, S. (2020). Implementation of the Tender by the Municipal Service Administration from the Aspect of Management in the Municipalities of the Republic of Serbia, Lex Localis - Journal of Local Self-Government, 8, 3: $469-486$.

[13] Terzić, D., Popović, V., Malić, N, Ikanović, J, Rajičić, V., Popović, S., Lončar, M \& Lončarević. V. (2019). Effects of long-term fertilization on yield of siderates andorganic matter content of soil in the process of recultivation. The J. Anim. Plant Sci. 29(3).

[14] Radović, M., Vitomir, J. and Popović, S. (2019). The Importance of Implementation of Internal Audit in Enterprises Founded by the Republic of Serbia, Lex Localis - Journal of Local Self-Government, 17, 4: 1001-1011. 
[15] Bjelica, B., Bakmaz, O., Mijić, R., Popović, S. and Popović, V. (2017). The implementation of heterogeneous risk to the company's operations and transition countries respecting the behavior of agricultural enterprises in the republic of Serbia. Annals, Economy Series, 3.

[16] Han, Y. (2017). Has the "Non-Clean" Internal Control Audit Opinion Received Sufficient Attention?-Evidence from the Perspective of Creditors, Journal of Central University of Finance and Economics, 8:57-64.

[17] Radović, M., Vitomir, J. \& Popović, S. (2021). Impact of internal control in enterprises founded by local self-government units: the case of Republic of Serbia, Inzinerine Ekonomika-Engineering Economics, 32(1): 82-90.

[18] Ugrenović, V., Popović, V., Ugrinović, M., Filipović, V., Mačkić, K., Ljubičić, N., Popović, S. \& Lakić, Ž. (2021). Black Oat (Avena strigosa Schreb.) Ontogenesis and Agronomic Performance in Organic Cropping System and Pannonian Environments, Agriculture 2021, 11(1): 55.

[19] Rodriguez, M., Miguel, Sanchez, L., Cejudo, E. and Antonio, C. (2019). Variety in local development strategies and employment: LEADER programme in Andalusia. Agric. Econ. Czech, 65: 43-50. 